\title{
The frequency of coexistent cardio-metabolic diseases in COVID-19 patients and their effects on clinical outcomes COVID-19 hastalarında eşlik eden kardiyo-metabolik
} hastalık sıklıkları ve klinik sonlanımlar üzerine etkileri

Mehmet Uzunlulu1 ${ }^{1}$, Haluk Vahapohlu², Ayse Naciye Erbakan ${ }^{1}$, Ummugulsum Durak ${ }^{1}$, Lutfullah Castur ${ }^{1}$, Onur Incealtin ${ }^{3}$, Ozlem Aydin ${ }^{2}$ ${ }^{1}$ Istanbul Medeniyet University, Goztepe Education and Research Hospital, Department of Internal Medicine, Istanbul, Turkey IIstanbul Medeniyet University, Goztepe Education and Research Hospital, Department of Infectious Diseases and Clinical Microbiology, Istanbul, Turkey

${ }^{3}$ Istanbul Medeniyet University, Goztepe Education and Research Hospital, Department of Emergency Medicine, Istanbul, Turkey

Submitted Date: 21 October 2021, Accepted Date: 17 November 2021
Correspondence: Ayse Naciye Erbakan

Istanbul Medeniyet University, Goztepe Education and Research

Hospital, Department of Internal Medicine, Istanbul, Turkey e-mail: erbakan553@hotmail.com

ORCID ID:

MU 0000-0001-8754-1069

HV 0000-0001-8217-1767

ANE 0000-0002-9047-6808

UD 0000-0002-8475-6918

LC 0000-0003-3908-6780

OI 0000-0001-6335-674X

OA 0000-0003-0398-9216

\section{SUMMARY}

Aim: We aimed to determine the frequency and characteristics of cardio-metabolic comorbidities (CMC) in patients hospitalized with the diagnosis of COVID-19 disease.

Material and Methods: In this retrospective study, 159 patients with a confirmed diagnosis of COVID-19 with polymerase chain reaction (PCR) were included out of 313 patients hospitalized with suspected COVID-19. CMC frequencies, patients characteristics, duration of hospitalizations, and clinical outcomes (discharge, death, ICU need) were determined.

Results: In COVID-19 patients, the frequencies of hypertension, diabetes mellitus, hyperlipidemia, coronary artery disease, chronic kidney disease, congestive heart failure, and cerebrovascular disease were 39\%, 24.5\%, 24.5\%, 20.1\%, 11.9\%, $9.4 \%$, and $8.2 \%$, respectively. There were 79 cases $(49.1 \%)$ with at least 1 CMC and 42 (26.1\%) cases with $\geq 3$ CMC. The median duration of hospitalization was four days, the mortality rate was $1.3 \%$, and the frequency of ICU need was $2.5 \%$. All CMC frequencies increased significantly with advancing age $(p<0.05$ for all). Compared to PCR negative cases, the mean duration of hospitalization $(p=0.001)$ was longer, and the frequency of hypertension $(p=0.008)$ was lower in PCR-positive COVID-19 patients.

Conclusion: Cardio-metabolic comorbidity frequencies in hospitalized COVID-19 patients were not higher than COVID-19 PCR negative cases and similar age groups without COVID-19 infection in national epidemiological studies. The presence of multiple CMCs were approximately one of every 4 cases, in all of those who died and in half of those who developed ICU needs, suggests that the coexistence of CMCs rather than their presence alone causes a cumulative risk increase on clinical outcomes associated with COVID-19.

Keywords: COVID-19, cardio-metabolic comorbidity, inpatient

\section{ÖZET}

Amaç: Koronavirus hastalığı 2019 (COVID-19) tanısıyla hastaneye yatan hastalarda kardiyo-metabolik komorbidite (KMK) sıklıklarının ve özelliklerinin belirlenmesi amaçladık.

Materyal ve Metodlar: Retrospektif, gözlemsel, klinik çalışmaya COVID-19 şüphesi ile hastaneye yatan 313 hastadan, polimeraz zincir reaksiyonu (PCR) ile konfirme COVID-19 tanısı olan 159 hasta alındı. KMK sıklıkları, hastaların özellikleri, yatı̧ süreleri ve klinik sonlanımları (taburcu, eksitus, YBÜ intiyacı) değerlendirildi.

Bulgular: COVID-19 hastalarında; hipertansiyon, diabetes mellitus, hiperlipidemi, koroner arter hastalığı, kronik böbrek hastalığı, konjestif kalp yetersizliği ve serebrovasküler hastalık sıklıkları sırasıyla; \%39, \%24,5, \%24,5, \%20,1, \%11,9, \%9,4 ve \%8,2 idi. En az 1 KMK olan 79 olgu $(\% 49,1)$, $\geq 3$ KMK olan $42(\% 26,1)$ olgu vardı. Medyan yatış süresi dört gün, mortalite sıklığı \%1,3, YBÜ intiyacı sıklığı \%2,5 idi. Yaş arttkça tüm KMK sıklıklarının anlamlı arttğı görüldü (tümü için $p<0.05$ ). PCR negatif olgulara göre PCR pozitif COVID-19 hastalarında ortalama yatış süresi $(p=0,001)$ uzun, hipertansiyon sıklığı $(p=0,008)$ düşüktü.

Sonuç: Hastaneye yatan COVID-19 hastalarında KMK sıklıklarının COVID-19 PCR negatif olgulara ve ulusal epidemiyolojik çalışmalardaki benzer yaş gruplarına göre yüksek bulunmadığı görülmüştür. Bununla birlikte yaklaşık her dört olgudan birinde, eksitus olanların tümünde ve YBÜ ihtiyacı gelişenlerin yarısında çoklu KMK varlığı, KMK'lerin tek başlarına varlıklarından ziyade bir arada bulunmalarının COVID-19 ile ilişkili klinik sonlanımlar üzerinde kümülatif bir risk artşına neden olduklarını düşündürmektedir.

Anahtar kelimeler: COVID-19, kardiyo-metabolik komorbidite, yatan hasta 


\section{INTRODUCTION}

In retrospective, observational studies, systematic reviews, and meta-analyses, although their frequency varies according to the population, it was shown that underlying cardiovascular disease and/or cardiac risk factors are common and that comorbidities such as hypertension $(\mathrm{HT})$, diabetes mellitus (DM), cardiovascular disease, chronic kidney disease (CKD), and cerebrovascular disease (CVD) are associated with increased disease severity and mortality, together with advanced age and male gender in patients with severe acute respiratory syndrome coronavirus 2 (SARS-CoV-2) (1-7). In the summary report of the Chinese Center for Disease Control and Prevention, the case-mortality rate was published as $2.3 \%$ in 44.672 confirmed COVID-19 cases. However, those with known comorbidities were reported to have much higher rates (10.5\% for cardiovascular disease, $7.3 \%$ for DM, 7.3\% for chronic respiratory disease. 6.3\% for HT, and $5.6 \%$ for cancer) (8). The COVID-19 pandemic continues globally, and at this stage, increasing the knowledge and sharing of comorbidity characteristics in COVID-19 patients and the management of cardio-metabolic diseases should be among the primary goals. This study aims to determine the frequency of cardio-metabolic comorbid diseases such as $\mathrm{HT}$, DM, coronary artery disease (CAD), congestive heart failure (CHF), hyperlipidemia (HL), CKD, and CVD in patients with COVID-19 infection and to determine whether cardiometabolic comorbid conditions differ according to age groups, duration of hospitalization and clinical outcomes (discharge, death, and intensive care need).

\section{MATERIAL AND METHODS}

In this single-center, retrospective, observational clinical study, 159 patients diagnosed with COVID-19 confirmed by polymerase chain reaction (PCR), out of a total of 313 patients hospitalized with suspected COVID-19 infection in Istanbul Medeniyet University Goztepe Training and Research Hospital between 21.03.2020 and 30.04.2020, were included consecutively. The trial protocol was approved by the hospital ethics committee (2020/0339) and conducted in accordance with the Declaration of Helsinki.

\section{Inclusion Criteria}

Adults (over 18 years old), laboratory confirmation of COVID-19 by real-time PCR, chest computed tomographic (CT) findings meeting the standard for diagnosis of COVID-19.

\section{Exclusion Criteria}

Missing data on clinical or laboratory characteristics, patients admitted to the intensive care unit (ICU).

\section{The Primary Endpoint of The Study}

Determination of the frequencies of cardio-metabolic comorbid diseases such as HT, DM, CAD, CHF, HL, CKD, and CVD in patients with COVID-19 infection.

\section{The Secondary Endpoint of The Study}

Evaluating whether the frequencies of cardio-metabolic comorbidity differ according to age groups, duration of hospitalization, and clinical outcomes (discharge, death, intensive care need).

\section{Study Design}

Age and gender characteristics, laboratory, and imaging data (complete blood count, random blood glucose, liver, and renal function, electrolytes, lactate dehydrogenase, ferritin, C reactive protein, procalcitonin, cardiac troponin I, coagulation function, and chest CT scan), clinical outcomes (discharge, death, intensive care need) of the patients who met the inclusion criteria were recorded. Three study researchers independently controlled the study data. In agreement with the WHO guidance, laboratory confirmation for SARS-Cov-2 was defined as a positive result of real-time reverse transcriptase-polymerase chain reaction (RTPCR) assay of nasal and pharyngeal swabs (9). Cardio-metabolic comorbidity definitions were determined by checking the patients' hospital records, clinical and laboratory findings, the drugs they have been used, and drug use reports of the patients for their current comorbidity conditions on the National Medula electronic prescription system (Medula System: https://medeczane. sgk.gov.tr/doktor/login.jsp).

The frequency of cardio-metabolic comorbidities in patients with COVID-19 and positive PCR were compared with COVID-19 PCR negative patients and also with the precious prevalence studies of DM, HT, and CKD that had been conducted in Turkey (10-12). It was assessed whether the frequencies of cardio-metabolic comorbidity differed according to age groups, duration of hospitalization, and clinical outcomes (discharge, death, intensive care need).

\section{Statistical Analysis}

NCSS (Number Cruncher Statistical System) program was used. Descriptive statistical methods (mean, standard deviation, median, frequency, percentage, minimum, maximum values) were used while evaluating the study data. The Shapiro-Wilk test and graphical analysis tested the compliance of quantitative data to normal distribution. Student t-test was performed to compare normally distributed quantitative variables between two groups, Mann-Whitney $U$ test was used to compare non-normally distributed variables between two groups. Kruskal-Wallis test and Dunn-Bonferroni test were performed to compare more than two groups of quantitative variables that did not show normal distribution. Pearson's chi-square test, Fisher's exact test, and Fisher-Freeman-Halton exact test were used to compare qualitative data. Statistical significance was accepted as $p<0.05$. 


\section{RESULTS}

Out of a total of 313 patients hospitalized with suspected COVID-19, 159 patients (87 men, 72 women, mean age: $57.2 \pm 16.9$ years) with a diagnosis of COVID-19 confirmed by PCR were included in the study.

In PCR confirmed COVID-19 patients, the frequencies of $\mathrm{HT}, \mathrm{DM}, \mathrm{HL}, \mathrm{CAD}, \mathrm{CKD}, \mathrm{CHF}$ and CVD were respectively $39 \%, 24.5 \%, 24.5 \%, 20.1 \%, 11.9 \%, 9.4 \%$ and $8.2 \%$. There were 79 cases $(49.1 \%)$ with at least 1 cardio-metabolic comorbidity, $42(26.1 \%)$ cases with $\geq 3$ cardio-metabolic comorbidity, the median duration of hospitalization was 4 days, the frequency of mortality was 1.3\% (2 cases), and the frequency of patients with ICU need was 2.5\% (4 cases). When compared with COVID-19 PCR negative cases, mean duration of hospitalization ( $p=0.001$ ), aspartate aminotransferase $(A S T)(p=0.001)$, ferritin $(p=0.002)$, creatine phosphokinase (CPK) $(p=0.047)$ and hemoglobin levels $(p=0.001)$ were high, hypertension frequency $(p=$ $0.008)$, sodium $(p=0.004)$, calcium $(p=0.001)$, leukocyte $(p=0.001)$, platelet $(p=0.001)$ and absolute lymphocyte $(p$ $=0.005$ ) levels were low in COVID-19 PCR positive patients (Table 1). The mean age, mean duration of hospitalization, clinical outcomes and cardio-metabolic comorbidity distributions were similar in males compared to females ( $p>0.05$ for all).

Table 1. Clinical characteristics of the cases

\begin{tabular}{|c|c|c|c|c|}
\hline & Total $(n=313)$ & $\begin{array}{c}\text { PCR confirmed } \\
\text { COVID-19 patients } \\
(n=159)\end{array}$ & $\begin{array}{c}\text { PCR negative } \\
\text { patients }(n=154)\end{array}$ & $\boldsymbol{P}$ \\
\hline Age (Mean $\pm S D$ ) & $58.49 \pm 16,91$ & $57.18 \pm 16,89$ & $59.85 \pm 16.88$ & 0.162 \\
\hline \multicolumn{5}{|l|}{ Outcome $n$ (\%) } \\
\hline Died & $4(1.3)$ & $2(1.3)$ & $2(1.3)$ & 1.000 \\
\hline Discharged & $302(96.5)$ & $153(96.2)$ & $149(96.8)$ & \\
\hline$I C U$ & $7(2.2)$ & $4(2.5)$ & $3(1.9)$ & \\
\hline $\begin{array}{l}\text { Duration of hospitalization } \\
\text { (median) }\end{array}$ & $4(3-6)$ & $4(3-7)$ & $3(2-4)$ & 0.001 \\
\hline \multicolumn{5}{|l|}{ Comorbidities n (\%) } \\
\hline Hypertension & $145(46.3)$ & $62(39.0)$ & $83(53.9)$ & 0.008 \\
\hline Diabetes mellitus & $84(26.8)$ & $39(24.5)$ & $45(29.2)$ & 0.349 \\
\hline Coronary artery disease & $75(24.0)$ & $32(20.1)$ & $43(27.9)$ & 0.106 \\
\hline Cerebrovascular disease & $24(7.7)$ & $13(8.2)$ & $11(7.1)$ & 0.731 \\
\hline Hyperlipidemia & $83(26.5)$ & $39(24.5)$ & $44(28.6)$ & 0.418 \\
\hline Chronic kidney disease & $39(12.5)$ & 19 (11.9) & $20(13.0)$ & 0.781 \\
\hline Congestive heart failure & $38(12.1)$ & $15(9.4)$ & $23(14.9)$ & 0.136 \\
\hline \multicolumn{5}{|l|}{ Laboratory } \\
\hline Glucose (mg/dL) (median) & $109(98-135)$ & $108(99-132)$ & $109,5(97-139)$ & 0.830 \\
\hline Creatinine (mg/dL) (median) & $0.84(0.74-1.08)$ & $0.86(0.75-1.09)$ & $0.84(0.72-1.08)$ & 0.267 \\
\hline AST (U/L) (median) & $25(19-37)$ & $27(22-40.5)$ & $21.5(16-30)$ & 0.001 \\
\hline ALT (U/L) (median) & $21(15-35)$ & $22(16-36)$ & $20(14-32)$ & 0.014 \\
\hline Sodium (mEq/L) (median) & $136(134-138)$ & $136(134-137)$ & $137(134-138)$ & 0.004 \\
\hline Potassium (mEq/L) (Mean $\pm S D)$ & $4.19 \pm 0.51$ & $4.18 \pm 0.48$ & $4.20 \pm 0.55$ & 0.727 \\
\hline Calcium (mg/dL) (Medyan) & $9(8-9)$ & $8.75(8-9)$ & $9(8.6-9)$ & 0.001 \\
\hline CRP (mg/dL) (median) & $3.34(0.65-8.73)$ & $4.02(0.89-8.21)$ & $2.85(0.37-9.26)$ & 0.429 \\
\hline $\begin{array}{l}\text { Procalcitonin }(\geq 0.05 \mathrm{ng} / \mathrm{mL}) n \\
\text { (\%) }\end{array}$ & $67(27.7)$ & 35 (26.9) & $32(28.6)$ & 0.775 \\
\hline LDH (U/L) (median) & $257(213.5-329)$ & $277.5(216-345)$ & $235.5(200-307)$ & 0.054 \\
\hline Ferritin ( $\mathrm{ng} / \mathrm{mL}$ ) (median) & $\begin{array}{l}171.1(78.1- \\
401.5)\end{array}$ & $\begin{array}{l}253.8(115.8- \\
462.66)\end{array}$ & $\begin{array}{c}76.25(20.11- \\
125.37)\end{array}$ & 0.002 \\
\hline CPK (U/L) (median) & $87.5(48-164)$ & $96.5(54-184)$ & $73(45.5-154.5)$ & 0.047 \\
\hline Troponin (>34 ng/L) $n$ (\%) & $26(9.7)$ & $11(8.2)$ & $15(11.2)$ & 0.409 \\
\hline INR (median) & $1.03(0.98-1.12)$ & $1.03(0.99-1.10)$ & $1.05(0.98-1.13)$ & 0.487 \\
\hline Leukocyte $\left(10^{\wedge} 3 / \mathrm{uL}\right)$ (median) & $\begin{array}{l}6700(5000- \\
9100)\end{array}$ & $6100(4700-7300)$ & $\begin{array}{l}7900(5800- \\
12000)\end{array}$ & 0.001 \\
\hline Haemoglobin $(\mathrm{g} / \mathrm{dL})($ Mean $\pm S D)$ & $12.94 \pm 1.84$ & $13.29 \pm 1.72$ & $12.59 \pm 1.90$ & 0.001 \\
\hline Platelet $\left(10^{\wedge} 3 / \mathrm{uL}\right)($ Mean $\pm S D)$ & $\begin{array}{c}206511.48 \pm 722 \\
45.16\end{array}$ & $\begin{array}{c}190464.52 \pm 63214 \\
26\end{array}$ & $\begin{array}{c}223093.33 \pm 7292 . \\
21\end{array}$ & 0.001 \\
\hline $\begin{array}{l}\text { Absolute number of } \\
\text { lymphocytes }\left(10^{\wedge} 3 / \mathrm{uL}\right) \\
\text { (median) }\end{array}$ & $\begin{array}{c}1275.3(966- \\
1814.5)\end{array}$ & $\begin{array}{c}1188.6(931- \\
1646.8)\end{array}$ & $\begin{array}{c}1474.3(1036- \\
1989.3)\end{array}$ & 0.005 \\
\hline $\begin{array}{l}\text { Lymphopenia (<80010^3/uL)) } \\
n(\%)\end{array}$ & $44(14.4)$ & $24(15.5)$ & $20(13.3)$ & 0.593 \\
\hline Positive & $287(91.7)$ & $145(91.2)$ & $142(92.2)$ & 0.745 \\
\hline Negative & $26(8.3)$ & $14(8.8)$ & $12(7.8)$ & \\
\hline
\end{tabular}

PCR: Polymerase chain reaction, AST: Aspartate aminotransferase, ALT: Alanine aminotransferase, CRP: C-reactive protein, LDH: Lactate dehydrogenase, CPK: Creatine phosphokinase, INR: International normalized ratio. 
It was observed that the frequency of all cardio-metabolic comorbidity increased significantly ( $p<0.05$ for all) as the age advanced (especially from $>60$ years of age) in patients with PCR confirmed COVID-19, and the frequency of HT, $D M$, and $H L$ decreased in the age group of $\geq 80$ years (Table 2). The mean duration of hospitalization did not differ significantly between cardio-metabolic comorbidities (Table 3).

The evaluations of COVID-19 PCR positive cases by the most common comorbidities: In patients with DM compared to the patients without DM; mean age $(65.2 \pm 14.4$ vs. $54.6 \pm 16.9, p=0.001)$, HT (74.4\% vs. $27.5 \%, p=0.001)$, CAD $(35.9 \%$ vs. $15 \%, p=0.005), H L(61.5 \%$ vs. $12.5 \%$, $\mathrm{p}=0.001)$ and $\operatorname{CKD}(23.1 \%$ vs. $8.3 \%, p=0.022)$ frequencies; In patients with HT compared to the patients without $\mathrm{HT}$; mean age (69 \pm 12.6 vs.49.6 $\pm 14.8, p=0.001), D M(46.8 \%$ vs. $10,3 \%, p=0.001), C A D(46.8 \%$ vs. $3.1 \%, p=0.001), C V D$ (21\% vs. $0 \%, p=0.001), \mathrm{HL}(51.6 \%$ vs. $7.2 \%, p=0.001), C K D$ (30.6\% vs. $0 \%, p=0.001)$ and $\operatorname{CHF}(21 \%$ vs. $2.1 \%, p=0.001)$ frequencies; In patients with CAD compared to the patients without $C A D$; mean age $(70.8 \pm 12.1$ vs.53.7 \pm 16.2 , $p=0.001)$, HT (90.6\% vs. $26 \%, p=0.001)$, DM $(43.8 \%$ vs. $19.7 \%, p=0.005), \operatorname{CVD}(28.1 \%$ vs. $3.1 \%, p=0.001), \mathrm{HL}(65.6 \%$ vs. $14.2 \%, p=0.001), \operatorname{CKD}(40.6 \%$ vs. $4.7 \%, p=0.001)$ and CHF (34.4\% vs. 3.1\%, $p=0.001)$ frequencies were high, and gender characteristics, mean duration of hospitalization and clinical outcomes were similar ( $p>0.05$ for all).

All those who died and developed ICU need were male. In those who need ICU, median duration of hospitalization $(p=0.001)$, and in those who died, CVD $(p=0.004), C K D$ $(p=0.019), C$ reactive protein levels $(p=0.027)$, frequency of procalcitonin elevation $(p=0.024)$, absolute lymphocyte count levels $(p=0.030)$, and frequency of patients with lymphopenia ( $p=0.021$ ) were higher (Table 4).

Characteristics of patients who died: The mean age was 69 years. Both cases were male. The cause of death was sudden cardiac arrest in one case and sudden respiratory failure in the other. In both cases, DM, HT, CKD, CAD, CVD, and $\mathrm{HL}$ were coexistent cardio-metabolic comorbidities, one case also had chronic obstructive pulmonary disease, and the other had the myelodysplastic syndrome.

Table 2. Cardio-metabolic comorbidity distribution of COVID-19 PCR positive cases by age groups

\begin{tabular}{|c|c|c|c|c|c|c|c|}
\hline & \multicolumn{6}{|c|}{ Age } & \multirow[b]{2}{*}{$P$} \\
\hline & $\begin{array}{c}<40 \\
(N=26)\end{array}$ & $\begin{array}{c}40-49 \\
(N=28)\end{array}$ & $\begin{array}{c}50-59 \\
(N=34)\end{array}$ & $\begin{array}{c}60-69 \\
(N=319)\end{array}$ & $\begin{array}{c}70-79 \\
(N=23)\end{array}$ & $\begin{array}{c}\geq 80 \\
(\mathrm{~N}=17)\end{array}$ & \\
\hline Hypertension; $n$ (\%) & $2(7.7)$ & $2(7.1)$ & $8(23.5)$ & $17(54.8)$ & $21(91.3)$ & $12(70.6)$ & 0.001 \\
\hline Diabetes mellitus; $n$ (\%) & $1(3.8)$ & $4(14.3)$ & $10(29.4)$ & $8(25.8)$ & $10(43.5)$ & $6(35.3)$ & 0.018 \\
\hline $\begin{array}{l}\text { Coronary artery disease; } \\
n(\%)\end{array}$ & $0(0.0)$ & $1(3.6)$ & $4(11.8)$ & $10(32.3)$ & $8(34.8)$ & $9(52.9)$ & 0.001 \\
\hline $\begin{array}{l}\text { Cerebrovascular disease; } \\
n(\%)\end{array}$ & $0(0.0)$ & $0(0.0)$ & $0(0.0)$ & $3(9.7)$ & $4(17.4)$ & $6(35.3)$ & 0.001 \\
\hline Hyperlipidemia; $n$ (\%) & $0(0.0)$ & $2(7.1)$ & $7(20.6)$ & $14(45.2)$ & $13(56.5)$ & $3(17.6)$ & 0.001 \\
\hline $\begin{array}{l}\text { Congestive heart failure; } \\
n(\%)\end{array}$ & $0(0.0)$ & $0(0.0)$ & $1(2.9)$ & $3(9.7)$ & $5(21.7)$ & $6(35.3)$ & 0.001 \\
\hline $\begin{array}{l}\text { Chronic kidney disease; } n \\
\text { (\%) }\end{array}$ & $1(3.8)$ & $0(0.0)$ & $0(0.0)$ & $4(12.9)$ & $7(30.4)$ & $7(41.2)$ & 0.001 \\
\hline
\end{tabular}

Table 3. Cardio-metabolic comorbidity distribution of COVID-19 PCR positive cases by the duration of hospitalization

\begin{tabular}{lcccc} 
& $\begin{array}{c}\text { Mean Duration } \\
\text { of Hospitalization } \\
\text { (days) }\end{array}$ & $\begin{array}{c}\mathbf{1 - 5} \text { days } \\
\text { (N=100) }\end{array}$ & $\begin{array}{c}\text { >6 days } \\
\text { (N=59) }\end{array}$ & $\boldsymbol{P}$ \\
\hline Hypertension; $n$ (\%) & $7.23 \pm 8.07$ & $37(37.0)$ & $25(42.4)$ & 0.502 \\
Diabetes mellitus; $n$ (\%) & $7.31 \pm 8.98$ & $22(22.0)$ & $17(28.8)$ & 0.335 \\
Coronary artery disease; $n$ (\%) & $5.72 \pm 4.80$ & $21(21.0)$ & $11(18.6)$ & 0.720 \\
Cerebrovascular disease; $n$ & $7,77 \pm 7.97$ & $7(7.0)$ & $6(10.2)$ & 0.554 \\
$(\%)$ & $6.72 \pm 8.59$ & $25(25.0)$ & $14(23.7)$ & 0.857 \\
Hyperlipidemia; $n$ (\%) & $7.60 \pm 6.41$ & $7(7.0)$ & $8(13.6)$ & 0.260 \\
Congestive heart failure; $n(\%)$ & $11(11.0)$ & $8(13.6)$ & 0.631 \\
Chronic kidney disease; $n$ (\%) & $5.90 \pm 5.03$ & 1 & & \\
\hline
\end{tabular}


Table 4. Clinical characteristics according to clinical outcomes in COVID-Positive Cases

\begin{tabular}{|c|c|c|c|c|}
\hline & $\begin{array}{c}\text { Discharged } \\
\text { (n=153) }\end{array}$ & ICU need $(n=4)$ & $\operatorname{Died}(n=2)$ & $\boldsymbol{P}$ \\
\hline Age; Median & $56(46-69)$ & $49(38-64)$ & $69(68-70)$ & 0.483 \\
\hline \multicolumn{5}{|l|}{ Gender $n(\%)$} \\
\hline Male & $81(52.9)$ & $4(100.0)$ & $2(100.0)$ & 0.085 \\
\hline Female & $72(47,1)$ & $0(0,0)$ & $0(0,0)$ & \\
\hline Duration of hospitalization & $4(3-7)$ & $24(16.5-40)$ & $2(2-2)$ & 0.001 \\
\hline \multicolumn{5}{|l|}{ Comorbidities $n$ (\%) } \\
\hline Hypertension & $58(37.9)$ & $2(50.0)$ & $2(100.0)$ & 0.161 \\
\hline Diabetes mellitus & $36(23.5)$ & $1(25.0)$ & $2(100.0)$ & 0.105 \\
\hline Coronary artery disease & $30(19.6)$ & $0(0.0)$ & $2(100.0)$ & 0.064 \\
\hline Cerebrovascular disease & $10(6.5)$ & $1(25.0)$ & $2(100.0)$ & 0.004 \\
\hline Hyperlipidemia & $36(23.5)$ & $1(25.0)$ & $2(100.0)$ & 0.105 \\
\hline Chronic kidney disease & $17(11.1)$ & $0(0.0)$ & $2(10.0)$ & 0.019 \\
\hline Congestive heart failure & $15(9.8)$ & $0(0.0)$ & $0(0.0)$ & 1.000 \\
\hline \multicolumn{5}{|l|}{ Laboratory (Median Value) } \\
\hline Glucose (mg/dL) & $107(98-132)$ & $124(119-255.5)$ & $165(129-201)$ & 0.077 \\
\hline Creatinine $(\mathrm{mg} / \mathrm{dL})$ & $0.87(0.75-1.09)$ & $0.78(0.71-0.82)$ & $1.64(1.64-1.64)$ & 0.156 \\
\hline AST $(U / L)$ & $26(22-40)$ & $42(30.5-108)$ & $40.5(35-46)$ & 0.074 \\
\hline $\operatorname{ALT}(U / L)$ & $22(16-35)$ & $64,5(45.5-121)$ & $29.5(19-40)$ & 0.016 \\
\hline Sodium $(\mathrm{mEq} / \mathrm{L})$ & $136(134-137)$ & $135(133-136.5)$ & $129.5(129-130)$ & 0.569 \\
\hline Potasyum (mEq/L) & $4.1(3.9-4.4)$ & $4.15(3.9-4.55)$ & $5.05(5-5.1)$ & 0.816 \\
\hline Calcium $(\mathrm{mg} / \mathrm{dL})$ & $8.75(8-9)$ & $9(8-9)$ & $8(8-8)$ & 0.780 \\
\hline $\mathrm{CRP}(\mathrm{mg} / \mathrm{dL})$ & $3.56(0.83-7.73)$ & $9.55(7.79-12.26)$ & $16.13(11.58-20.68)$ & 0.027 \\
\hline Procalcitonin $(\geq 0.05) n(\%)$ & $31(25.0)$ & $2(50.0)$ & $2(100.0)$ & 0.024 \\
\hline LDH (U/L) & $269(216-339)$ & $523(503-524)$ & $446.5(435-458)$ & 0.007 \\
\hline Ferritin $(\mathrm{ng} / \mathrm{mL})$ & $\begin{array}{c}219.3(108.6- \\
348.0)\end{array}$ & $\begin{array}{c}599.6(498.1- \\
3132.7)\end{array}$ & - & 0.015 \\
\hline $\mathrm{CPK}(\mathrm{U} / \mathrm{L})$ & $94.5(54-183.5)$ & $148.5(77.5-210)$ & $414(33-795)$ & 0.685 \\
\hline Troponin (>34 ng/L) n (\%) & $11(8.5)$ & $0(0.0)$ & $0(0.0)$ & 1.000 \\
\hline INR & $1.03(0.98-1.10)$ & $1.04(0.96-1.10)$ & $1.1(1.09-1.10)$ & 0.805 \\
\hline White blood cell & $6100(4700-7100)$ & $7650(6600-12400)$ & $6400(6100-6700)$ & 0.064 \\
\hline Hemoglobin & $13.6(12.3-14.2)$ & $13.6(12.9-14.2)$ & $11.5(10.9-12.1)$ & 0.810 \\
\hline Platelet & $\begin{array}{c}182000(146000- \\
230000)\end{array}$ & $\begin{array}{c}191500(159000- \\
324000)\end{array}$ & $\begin{array}{c}164000(112000- \\
216000)\end{array}$ & 0.430 \\
\hline Absolute lymphocyte count & $\begin{array}{c}1222(958.8- \\
1661.4)\end{array}$ & $\begin{array}{c}858.3(774.55- \\
931.4)\end{array}$ & $449.4(262.3-636.5)$ & 0.030 \\
\hline $\begin{array}{l}\text { Absolute lymphocyte } \\
\text { count of }(<800) n(\%)\end{array}$ & $21(14.1)$ & $1(25.0)$ & $2(100.0)$ & 0.021 \\
\hline \multirow{2}{*}{ Imaging $n(\%)$} & $139(90.8)$ & $4(100.0)$ & $2(100.0)$ & 1.000 \\
\hline & $14(9.2)$ & $0(0.0)$ & $0(0.0)$ & \\
\hline
\end{tabular}

ICU: Intensive care unit, AST: Aspartate aminotransferase, ALT: Alanine aminotransferase, CRP: C-reactive protein, LDH: Lactate dehydrogenase, CPK: Creatine phosphokinase, INR: International normalized ratio.

Characteristics of patients who needed ICU: The mean age was 49 years. All of them were male. DM and CVD in one case, $H T, D M$, and $H L$ in the other case were the coexistent cardio-metabolic comorbidities, and 2 cases had no accompanying comorbidities.

Treatment characteristics used by the patients for comorbid conditions: Of those with hypertension, 31 patients were using angiotensin-converting enzyme inhibitors, 16 patients angiotensin receptor blockers, 23 patients calcium channel blockers, 37 patients betablockers, 31 patients thiazide diuretics, and eight patients alpha-blockers; of patients with DM, 32 patients were using oral anti-diabetic medications, 14 patients insulin and 11 patients both oral anti-diabetic medications and insulin; of those with hyperlipidemia 31 patients were using statins, three patients fenofibrate, and three patients both statin and fenofibrate.

\section{DISCUSSION}

In this study, the frequencies of cardio-metabolic diseases or risk factors were observed not to be higher in COVID-19 PCR positive patients than COVID-19 PCR negative patients and similar age groups without COVID-19 infection in national epidemiological studies. At the same time, the coexistence of three or more cardio-metabolic diseases or risk factors in one of every four cases suggests that the 
clustering of cardio-metabolic comorbidities, as well as advanced age and male gender, have negative effects on mortality and ICU need in these cases.

Increasing data show that cardio-metabolic diseases and other comorbidities are common in SARS-CoV-2 patients and are associated with increased disease severity and mortality. In a retrospective, multicenter cohort study conducted in China, it was shown that comorbidities accompany $48 \%$ of the patients, and these patients have DM (19\%) and CAD (8\%), the most common being HT (30\%) (7). In a retrospective series of 393 cases (mean age: 62.2 years, $60 \%$ male) who were hospitalized consecutively with a confirmed COVID-19 diagnosis in New York, it was observed that DM was accompanied by $25.2 \%$, HT in $50.1 \%$, and CAD in $13.7 \%$ (13). In our study, approximately two-fifths of patients hospitalized with the diagnosis of COVID-19 had HT, approximately one-quarter had DM or $\mathrm{HL}$, approximately one-fifth had CAD, and approximately one out of every ten patients had CKD or CHF, which seems consistent with the results of other studies. However, whether the frequency of cardio-metabolic comorbid conditions, especially HT or type $2 \mathrm{DM}$, is high in patients with COVID-19 should be interpreted considering the general population characteristics. Because the prevalence of HT and type 2 DM have increased globally throughout the world, and it is known that their frequency increases in parallel with increasing age groups. In epidemiological studies, the frequency of HT in Turkey was 30\%, the frequency of diabetes was $16.5 \%$, and the frequency of CKD was $15.7 \%$ (10-12). In our study, although the frequency of patients with HT and DM seems to be slightly higher than the general population, except for CKD, it was not found to be higher when compared with similar age groups in epidemiological studies. On the other hand, when compared with COVID-19 PCR negative cases, the frequency of cardio-metabolic comorbidity except HT was similar, supporting this view.

It is controversial whether each of the cardio-metabolic comorbidities associated with COVID-19 disease, which are known to affect the course and mortality of the disease, is an independent risk factor for mortality alone or whether their coexistence plays a role in the increase in mortality. For example, in a retrospective study reported from China, although the frequency of ICU hospitalization and mortality was higher in patients with COVID-19 with diabetes compared to patients with COVID-19 without diabetes, in multivariate Cox regression analysis, HT, cardiovascular disease, and chronic pulmonary disease were found to be independently associated with inhospital mortality, and after adjustment, diabetes was not statistically significantly associated with in-hospital mortality (14). In that study, it was reported that advanced age ( $\geq 70$ years) and coexistent $\mathrm{HT}$ in diabetic patients were independent risk factors for in-hospital death. In our study, both patients with mortality and half of the patients in need of intensive care consisted of middle-aged male patients and the fact that they had multiple comorbidities such as DM, HT, CAD, CKD, CVD, and HL suggest that the clustering of cardio-metabolic diseases, rather than the presence of a cardiometabolic risk factor or disease alone, maybe the main factor underlying the poor outcomes in patients with COVID-19. The fact that no significant difference was found between cardio-metabolic comorbidities in terms of gender, duration of hospitalization and clinical outcomes in our study seems to support this finding.

An important finding that drew our attention in our study is that the frequency of $\mathrm{HL}$ was detected in approximately one of every four patients. When our data were examined, it was observed that DM and HT coexisted in 30 cases (18.6\%), and DM, HT, and HL coexisted in 21 (13\%) cases. This finding raises the question of whether a cluster of cardio-metabolic risk factors accompanied by $\mathrm{HL}$ with HT and DM, the presence of a possible metabolic syndrome (MetS) will be considered as a risk factor associated with both infection predisposition and cumulatively mortality in COVID-19. The coexistence of DM, HT, and HL in 2 cases who died and 1 case in ICU need supports this idea. MetS is a cluster of cardiometabolic risk factors characterized by hyperglycemia, high blood pressure, abdominal obesity, low HDL cholesterol, and high triglycerides, and it is known that all parameters other than dyslipidemia negatively affect the course of COVID-19. MetS is also a proinflammatory and procoagulant condition, and in this respect, it may increase the tendency for hyper inflammation and cytokine storm syndrome observed in COVID-19 $(15,16)$. Focusing mainly on treating the disease in COVID-19 patients causes the measurement of obesity markers such as waist circumference or body mass index and lipid subgroups to be generally ignored, which seems to be the most critical obstacle to understanding the presence and importance of MetS in COVID-19 patients. The COVID-19 pandemic is continuing, and the role of MetS in COVID-19 physiopathology will be better understood with large-scale studies where obesity parameters and lipid subgroups can be evaluated.

In our study, the high levels of liver enzymes, ferritin and CPK, and low leukocyte, absolute lymphocyte count, sodium, and calcium levels in COVID-19 PCR positive cases, compared to COVID-19 PCR negative cases, seemed compatible with the literature data (17).

Limitations of the study: Because of the retrospective design, although the definition of comorbid conditions was checked from the National Data Tables, the fact that it was based on hospital records, the uncertainty of the duration of comorbidity, the lack of distinction between type 1 and type 2 diabetes, and the fact that patients who were admitted directly to the ICU were not included in the study, except for patients who needed an ICU, constitute the study's limitations. 


\section{CONCLUSION}

Although the frequency of cardio-metabolic comorbidity was not found to be high in patients hospitalized due to COVID-19 in this study, and in addition to the advanced age and male gender, it was observed that the clustering of cardio-metabolic diseases or risk factors, the presence of possible MetS had negative effects on mortality and ICU need.

Author Contributions: Working Concept/Design: MU, Data Collection: ANE, UD, LC, Data Analysis / Interpretation: HV, OI, OA, Text Draft: MU, Critical Review of Content: MU, HV, ANE, UD, LC, OI, OA, Final Approval and Responsibility: $\mathrm{MU}, \mathrm{HV}, \mathrm{ANE}, \mathrm{OI}, \mathrm{OA}$, Material and technical support: UD, LC, Supervision: MU, HV

Conflict of Interest: The authors state that there is no conflict of interest regarding this manuscript.

Financial Disclosure: The authors of this study stated that they did not receive any financial support.

\section{REFERENCES}

1. Yang $X, Y u Y, X u$ J, Shu $H$, Xia J, Liu H, et al. Clinical course and outcomes of critically ill patients with SARSCoV-2 pneumonia in Wuhan, China: a single-centered, retrospective, observational study. Lancet Respir Med 2020;8(5):475-81. doi: 10.1016/S2213-2600(20)30079-5.

2. Guan WJ, Ni ZY, Hu Y, Liang WH, Ou CQ, He JX et al. Clinical Characteristics of Coronavirus Disease 2019 in China. N Engl J Med 2020;382(18):1708-20. doi: 10.1056/ NEJMoa2002032.

3. Zhang JJ, Dong X, Cao YY, Yuan YD, Yang YB, Yan YQ, et al. Clinical characteristics of 140 patients infected with SARSCoV-2 in Wuhan, China. Allergy 2020;75(7):1730-41. doi: 10.1111/all.14238.

4. Emami A, Javanmardi F, Pirbonyeh N, Akbari A. Prevalence of Underlying Diseases in Hospitalized Patients with COVID-19: a Systematic Review and Meta-Analysis. Arch Acad Emerg Med 2020;8(1):e35. eCollection 2020.

5. Li B, Yang J, Zhao F, Zhi L, Wang X, Liu L, et al. Prevalence and impact of cardiovascular metabolic diseases on COVID-19 in China. Clin Res Cardiol 2020;109(5):531-8. doi: 10.1007/s00392-020-01626-9.

6. Madjid M, Safavi-Naeini P, Solomon SD, Vardeny O. Potential Effects of Coronaviruses on the Cardiovascular System: A Review. JAMA Cardiol 2020;5(7):831-40. doi: 10.1001/jamacardio.2020.1286.

7. Wang X, Fang X, Cai Z, Wu X, Gao X, Min J, et al. Comorbid Chronic Diseases and Acute Organ Injuries Are Strongly Correlated with Disease Severity and Mortality among COVID-19 Patients: A Systemic Review and MetaAnalysis. Research (Wash D C) 2020 Apr 19;2020:2402961. doi: 10.34133/2020/2402961.

8. Wu Z, McGoogan JM. Characteristics of and Important Lessons From the Coronavirus Disease 2019 (COVID-19)
Outbreak in China: Summary of a Report of 72314 Cases From the Chinese Center for Disease Control and Prevention. JAMA 2020;323(13):1239-42. doi: 10.1001/ jama.2020.2648.

9. World Health Organization. Clinical management of severe acute respiratory infection when novel coronavirus (2019-nCoV) infection is suspected: interim guidance [Internet], 2020. [Cited 28 January 2020] Available from https://apps.who.int/iris/bitstream/ handle/10665/330893/WHO-nCoV-Clinical-2020.3-eng. pdf?sequence 51\&isAllowed5y.

10. Sengul S, Akpolat T, Erdem $Y$, Derici U, Arici $M$, Sindel S, et al; Turkish Society of Hypertension and Renal Diseases. Changes in hypertension prevalence, awareness, treatment, and control rates in Turkey from 2003 to 2012. J Hypertens 2016;34:1208-17. doi: 10.1097/ HJH.0000000000000901.

11. Satman I, Omer B, Tutuncu Y, Kalaca S, Gedik S, Dinccag $\mathrm{N}$, et al; TURDEP-II Study Group. Twelve-year trends in the prevalence and risk factors of diabetes and prediabetes in Turkish adults. Eur J Epidemiol 2013;28:169-80. doi: 10.1007/s10654-013-9771-9775.

12. Süleymanlar G, Utaş C, Arinsoy $T$, Ateş K, Altun B, Altiparmak MR, et al. A population-based survey of Chronic REnal Disease In Turkey--the CREDIT study. Nephrol Dial Transplant 2011;26(6):1862-71. doi: 10.1093/ndt/gfq656. 13. Goyal P, Choi JJ, Pinheiro LC, Schenck EJ, Chen R, Jabri A, et al. Clinical Characteristics of Covid-19 in New York City. N Engl J Med 2020;382(24):2372-4. doi: 10.1056/ NEJMc2010419.

14. Shi Q, Zhang X, Jiang F, Zhang X, Hu N, Bimu C, et al. Clinical Characteristics and Risk Factors for Mortality of COVID-19 Patients With Diabetes in Wuhan, China: A Two-Center, Retrospective Study. Diabetes Care 2020;43(7):1382-91. doi: 10.2337/dc20-0598.

15. Costa FF, Rosário WR, Ribeiro Farias AC, de Souza RG, Duarte Gondim RS, Barroso WA. Metabolic syndrome and COVID-19: An update on the associated comorbidities and proposed therapies. Diabetes Metab Syndr 2020;14(5):809-14. doi: 10.1016/j.dsx.2020.06.016.

16. Chocair PR, Neves PDMM, Pereira LVB, Mohrbacher S, Oliveira ES, Nardotto LL, et al. Covid-19 and Metabolic Syndrome. Rev Assoc Med Bras (1992) 2020;66(7):871-5 doi: 10.1590/1806-9282.66.7.871.

17. Henry BM, de Oliveira MHS, Benoit S, Plebani M, Lippi G. Hematologic, biochemical and immune biomarker abnormalities associated with severe illness and mortality in coronavirus disease 2019 (COVID-19): a meta-analysis. Clin Chem Lab Med 2020 Jun 25;58(7):1021-8. doi: 10.1515/cclm-2020-0369. 